\title{
The Difference in Body Temperature Measured on the Tympanic Membrane, in the Axilla and with Infrared Sensor Thermometer in Pulmonary Intensive Care Patients
}

1 Kornelija Erdelja

2 Snježana Čukljek

2 Janko Babić

1 University Hospital Centre Zagreb, Clinic for lung diseases Jordanovac

2 University of Applied Health Sciences in Zagreb

Article received: 21.02 .2018 .

Article accepted: 20.04.2018.

Author for correspondence:

Kornelija Erdelja

University Hospital Centre Zagreb, Clinic for lung diseases Jordanovac, Department of respiratory insufficiency and the diseases of pulmonary circulation, Intensive Care Unit, Jordanovac 104, Zagreb, Croatia

E-mail: kornelijaerdelja@gmail.com

DOI: $10.24141 / 2 / 2 / 1 / 4$

Keywords: body temperature, tympanic membrane, axilla, infrared sensor thermometer

\section{Abstract}

Introduction. Measurement of body temperature in an intensive care unit is a standard procedure that provides quick insight into the patient's condition and possible changes in that condition. The measurement is carried out at different parts of the body and with the help of different thermometers. Patients in intensive care units are hemodynamically unstable, subjected to various invasive methods, and temperature indicates possible changes in their condition.

Aim. The aim of this research was to determine if there are differences between the body temperature values measured in the axilla, on the tympanic membrane and using the infrared sensor thermometer on the patient's forehead with regard to the age, gender and the diagnosis of the patient.

Methods. The research was carried out in the Intensive Care Unit of the Clinic for lung diseases Jordanovac, in the period from January 2 nd to July 2 nd 2017. Author of the research did the measurements by herself during her work shifts. Research included 100 patients. Methods that were used were descriptive statistics (measures of central tendency, arithmetic mean, median and mod) and measures of variability (standard deviation, minimum and maximum). One-way analysis of variance (ANOVA) was also conducted.

Results. A statistically significant difference was determined in the measured temperature values using the infrared sensor thermometer on the patients' 
forehead which were higher than the axillary and tympanic temperatures in male patients, patients younger than 70 years and in patients with COPD.

Conclusion. It is important to choose the adequate method of body temperature measurement, taking into account the peculiarities and the clinical condition of the patient, and the advantages and disadvantages of each measurement procedure. It is necessary to combine or repeat measurements in order to be completely sure of the obtained values. In patients in pulmonary intensive care units taking axillary temperature is recommended.

\section{Introduction}

Body temperature is an important vital sign measured every day, few times a day in pulmonary intensive care units in order to have an insight into the patient's condition. Body heat is constantly created by the exchange of matter in tissue cells and organs (core temperature), and is released into the environment at the surface of the body (peripheral temperature) by radiation, evaporation, sweat and body fluids (1). The hypothalamus and its control center for body temperature (preoptic frontal area of the hypothalamus) play the main role in the regulation of body temperature (2). Most nerves are sensitive to heat, and a small part is sensitive to cold. When nerves are warming up the body starts to sweat, and when they are cooling down every mechanism for controlling heat loss is inhibited. There are more cold receptors in the body periphery and they are all controlled by the hypothalamus. Heat receptors can also be found in the deep tissue and they are exposed to the core body temperature. Specific factors that have an impact on the body temperature are a 24-hour rhythm (body temperature is lower in the morning and higher in the afternoon), hormones (progesterone increases body temperature) and emotions (anxiety also increases body temperature) (3).

Most body heat is created in the muscles and liver, excess of heat is given out of the organism, mostly through skin, by process of radiation, convection, conduction and evaporation (4). Radiation is the process of losing heat to the environment by radiating, and in this way about $60 \%$ of the heat is lost. Convection is releasing heat to the environment by airflow, and in this way about $12 \%$ of the heat is lost. The conduction is the loss of the heat by transferring heat directly from the body surface to other objects (e.g. bed), in such a way only about $3 \%$ of the heat is lost because the objects in the environment heat up fast. Evaporation is the process of losing heat through the evaporation of water from the surface of the body. This is a particularly important way of releasing heat at high environment temperature, when an organism does not lose heat by radiation and convection but receives it (when the environment temperature is higher than the body temperature, then the body begins to receive heat instead of losing it to the environment) (4).

Body temperature is measured for a number of reasons - to assess the patient's condition upon admission and to determine the important changes in the patient's condition in the shortest time possible. While taking the body temperature, we want to measure the core body temperature (5), and in patients in intensive care units this most often involves insertion of a catheter in the pulmonary artery (5). Other invasive methods of measuring the body temperature include measuring the temperature in the esophagus, urinary bladder, large intestine, while methods used more frequently are non-invasive methods such as measuring the temperature orally, in the axilla, on the tympanic membrane $(5,6)$ and with an infrared sensor thermometer on the patient's forehead.

Out of non-invasive methods used in practice in Croatia the most used in adult patients are measuring body temperature in the axilla, on the tympanic membrane and lately, using the infrared sensor thermometer on the temporal artery.

A lot of factors affect the measured body temperature values such as the position of the thermometer, sweaty forehead when measuring the temperature with infrared sensor thermometer, a lot of cerumen in the ear, lying on one's ear or the accuracy of the thermometer (dirty lens) (7). While interpreting the measured values it is important to indicate the place of measurement so that the values would not be considered as elevated.

Body temperature value is an important vital sign in pulmonary intensive care patients based on which a series of diagnostic and therapeutic procedures are determined, so the place of measurement and the measurement procedure is highly important. 
The aim of this research was to determine if there are differences in body temperature values measured in the axilla, on the tympanic membrane and with the infrared sensor thermometer on the patient's forehead, and to determine if there are differences between the measured values with regard to the age, gender and diagnosis of the patient. The research was conducted because of frequent differences in the measured values with regard to the method of measurement in a large number of patients.

\section{Methods}

There were 100 subjects that participated in the research, 63 of them were male and 37 were female. During data analysis, with regard to the medical diagnosis, we statistically compared the subjects with medical diagnosis that occurred in more than 10 patients. There were 32 patients with COPD, 25 with pneumonia, and 11 patients with embolism. The rest of the diagnoses included: the condition after transplantation, pulmonary hypertension, hemoptoe, fibrosis, tracheal stenosis (32 patients). Subjects were divided into three groups with regard to the age of the patient. There were 20 patients up to 55 years of age, 45 patients from $56-70$ years and 35 patients older than 71 years of age.

The research was conducted over a 6-month period, from January 2nd till July 2nd 2017 and it included all the patients in the Intensive Care Unit of the University Hospital Centre Zagreb, Clinic for lung diseases Jordanovac, regardless of their medical diagnosis, gender or age. The author of the research did measurements on all the subjects by herself during her shifts. The measurements were made on the tympanic mem- brane, in the axilla and on patients' forehead using the infrared sensor thermometer. The average time for temperature measurement was around 10 minutes. The author respected the standards for the measurement of body temperature with an infrared sensor thermometer on the patient's forehead, with an electronic thermometer in the ear (on the tympanic membrane), and in the axilla. The standards were created in the University Hospital Centre Zagreb and published in Alfresco. The obtained results were processed using descriptive statistics (measures of central tendency, arithmetic mean, median and mod) and measures of variability (standard deviation, minimum and maximum). One-way variance analysis (ANOVA) was also used for repeated measurements (One-way Repeated Measures ANOVA). In the obtained results $p$-value that is considered statistically important is $p<0.05$.

\section{Results}

There is a statistically significant difference in body temperature measurements in the total sample of patients $(p<0.01)$.

There is a statistically significant difference in the measured body temperature values between different methods of measurement. Higher body temperature values were obtained while measuring body temperature using the infrared sensor thermometer on the patients' forehead (Table 1).

There is a statistically significant difference in body temperature measurements in male patients $(p<0.01)$.

There is a statistically significant difference in the measured values in male patients, where there is a statistically significant difference between meas-

\begin{tabular}{|c|c|c|c|}
\hline & M & SD & $\mathbf{N}$ \\
\hline Tympanic membrane & 36.677 & 0.6969 & 100 \\
\hline Axilla & 36.688 & 0.5973 & 100 \\
\hline Infrared sensor thermometer & 36.890 & 0.4951 & 100 \\
\hline
\end{tabular}




\begin{tabular}{cccc}
\hline Table 2. Bonferroni post hoc test of differences in body temperature between different methods \\
of measurement
\end{tabular}

\begin{tabular}{|c|ccc|}
\hline $\begin{array}{c}\text { Table 3. Difference in body temperature in male patients with regard to the method of } \\
\text { measurement }\end{array}$ & M & SD & N \\
\hline Tympanic membrane & 36.590 & 0.7602 & 63 \\
\hline Axilla & 36.644 & 0.6380 & 63 \\
\hline Infrared sensor thermometer & 36.875 & 0.5208 & 63 \\
\hline
\end{tabular}

\begin{tabular}{|cccc|}
\hline \multicolumn{2}{|c|}{ Table 4. Bonferroni post-hoc test of differences between individual methods of body temperature } \\
measurement in male patients
\end{tabular}

\begin{tabular}{|c|c|c|c|}
\hline & M & SD & $\mathbf{N}$ \\
\hline Tympanic membrane & 36.824 & 0.5520 & 37 \\
\hline Axilla & 36.762 & 0.5209 & 37 \\
\hline Infrared sensor thermometer & 36.916 & 0.4537 & 37 \\
\hline
\end{tabular}

uring body temperature with the infrared sensor thermometer and measurements in the axilla or on the tympanic membrane. Higher body temperature values were obtained using the infrared sensor thermometer (Table 3).

There is no statistically significant difference in body temperature measurements in female patients $(p>0.05)$.
There is a statistically significant difference in body temperature measurements in patients up to 55 years of age $(p<0.05)$.

There is a statistically significant difference between methods of body temperature measurements in patients up to 55 years of age, between the measurements in the axilla and using the infrared sensor thermometer. Higher body temperature values were 


\section{Table 6. Difference in body temperature in patients up to 55 years of age with regard to the method of measurement}

\begin{tabular}{ccccc} 
& S & SD & N \\
\hline Tympanic membrane & 36.865 & 0.5284 & 20 \\
\hline Axilla & 36.615 & 0.5224 & 20 \\
\hline Infrared sensor thermometer & 36.940 & 0.4882 & 20 \\
\hline
\end{tabular}

\begin{tabular}{|c|c|c|c|}
\hline Method of measurement(I) & Method of measurement(J) & $M(I-J)$ & $\mathbf{P}$ \\
\hline Tympanic membrane & $\begin{array}{c}\text { Axilla } \\
\text { Infrared sensor thermometer }\end{array}$ & $\begin{array}{l}.250 \\
-.075\end{array}$ & $\begin{array}{l}0.182 \\
1.000\end{array}$ \\
\hline Axilla & $\begin{array}{c}\text { Tympanic membrane } \\
\text { Infrared sensor thermometer }\end{array}$ & $\begin{array}{l}-.250 \\
-.325\end{array}$ & $\begin{array}{l}0.182 \\
0.007\end{array}$ \\
\hline Infrared sensor thermometer & $\begin{array}{l}\text { Tympanic membrane } \\
\text { Axilla }\end{array}$ & $\begin{array}{l}.075 \\
.325\end{array}$ & $\begin{array}{l}1.000 \\
0.007\end{array}$ \\
\hline
\end{tabular}

\section{Table 8. Difference in body temperature in patients from $56-70$ years of age with regard to the} method of measurement

\begin{tabular}{cccc} 
& M & SD & N \\
\hline Tympanic membrane & 36.662 & 0.7759 & 45 \\
Axilla & 36.691 & 0.6660 & 45 \\
\hline Infrared sensor thermometer & 36.958 & 0.5639 & 45 \\
\hline
\end{tabular}

\section{Table 9. Bonferroni post-hoc test of differences between individual methods of body temperature measurement in patients from 56-70 years of age}

$\begin{array}{cccc}\text { Method of measurement(I) } & \text { Method of measurement(J) } & \text { M(I-J) } & \text { P } \\ \text { Tympanic membrane } & \text { Axilla } & -.029 & 1.000 \\ & \text { Infrared sensor thermometer } & -.296 & 0.001 \\ \text { Axilla } & \text { Tympanic membrane } & .029 & 1.000 \\ & \text { Infrared sensor thermometer } & -.267 & 0.000 \\ \text { Infrared sensor thermometer } & \text { Tympanic membrane } & .296 & 0.001 \\ & \text { Axilla } & .267 & 0.000\end{array}$

obtained using the infrared sensor thermometer on the patients' forehead (Table 6).

There is a statistically significant difference in body temperature measurements in patients from $56-70$ years of age $(p<0.01)$.

There is a statistically significant difference between methods of body temperature measurements in patients from $56-70$ years of age, where the measurement using an infrared sensor thermometer is different from the tympanic membrane and axilla measurements. Higher body temperature values were obtained using an infrared sensor thermometer on the patients' forehead (Table 8).

There is no statistically significant difference in body temperature measurements in patients older than 70 years of age $(p>0.05)$. 


\section{Table 10. Difference in body temperature in patients older than 70 years of age with regard to} the method of measurement

$\begin{array}{cccc} & \text { M } & \text { SD } & \text { N } \\ \text { Tympanic membrane } & 36.589 & 0.6707 & 35 \\ \text { Axilla } & 36.726 & 0.5548 & 35 \\ \text { Infrared sensor thermometer } & 36.774 & 0.3845 & 35\end{array}$

$F=2.397 ; d f=2.68 ; p=0.099$

Table 11. Difference in body temperature in patients with COPD with regard to the method of measurement

$\begin{array}{cccc} & \text { M } & \text { SD } & \text { N } \\ \text { Tympanic membrane } & 36.613 & 0.6394 & 32 \\ \text { Axilla } & 36.613 & 0.5253 & 32 \\ \text { Infrared sensor thermometer } & 36.894 & 0.4724 & 32\end{array}$

$F=7.975 ; \mathrm{df}=2.62 ; \mathrm{p}=0.001$

Table 12. Bonferroni post-hoc test of differences between the individual methods of body temperature measurements in patients with COPD

$\begin{array}{cccc}\text { Method of measurement(I) } & \text { Method of measurement(J) } & \text { M(I-J) } & \text { P } \\ \text { Tympanic membrane } & \text { Axilla } & .000 & 1.000 \\ & \text { Infrared sensor thermometer } & -.281 & 0.012 \\ \text { Axilla } & \text { Tympanic membrane } & .000 & 1.000 \\ & \text { Infrared sensor thermometer } & -.281 & 0.001 \\ \text { Infrared sensor thermometer } & \text { Tympanic membrane } & .281 & 0.012 \\ & \text { Axilla } & .281 & 0.001\end{array}$

Table 13. Differences in body temperature in patients with pneumonia with regard to the method of measurement

\begin{tabular}{|cccc|}
\hline & M & SD & N \\
\hline Tympanic membrane & 36.864 & 0.7239 & 25 \\
\hline Axilla & 36.860 & 0.6690 & 25 \\
\hline Infrared sensor thermometer & 37.032 & 0.6517 & 25 \\
\hline
\end{tabular}

There is a statistically significant difference in body temperature measurements in patients with COPD $(p<0.01)$.

There is a statistically significant difference in methods of body temperature measurement in patients with COPD, where the measurement using an infrared sensor thermometer is different from the tympanic membrane and axilla measurements. Higher body temperature values were obtained using the infrared sensor thermometer on patients' forehead (Table 11).

There is no statistically significant difference in body temperature measurements in patients with pneumonia ( $p>0.05)$.

There is no statistically significant difference in body temperature measurements in patients with embolism ( $p>0.05)$. 
Table 14. Differences in body temperature in patients with embolism with regard to the method of measurement

\begin{tabular}{|c|c|c|c|}
\hline & $\mathbf{M}$ & SD & $\mathbf{N}$ \\
\hline Tympanic membrane & 36.882 & 0.5076 & 11 \\
\hline Axilla & 36.600 & 0.5292 & 11 \\
\hline Infrared sensor thermometer & 36.909 & 0.3618 & 11 \\
\hline
\end{tabular}

\section{Discussion}

The most common way of body temperature measurement in our clinical practice is in the axilla. However, in recent times body temperature is more often measured on the tympanic membrane and using the infrared sensor thermometer on patients' forehead. Since the value of body temperature is a very important information while caring for the patients in pulmonary intensive care unit, we wanted to determine if there are differences present between body temperature values measured in the axilla, on the tympanic membrane and using the infrared sensor thermometer on the patient's forehead.

There is a statistically significant difference in the measured body temperature values in the total patient sample. Higher values of body temperature were obtained using an infrared sensor thermometer than the ones measured in the axilla and on the tympanic membrane. Barringer and associates obtained the similar results in their study conducted on preoperative and postoperative patients. They have determined that there are higher body temperature differences in preoperative patients measured on the temporal artery than in the axilla, while the average postoperative body temperature values where the same whether they were measured in the axilla or on the temporal artery (8).

Antabak and associates compared the body temperature values measured in the axilla, using the infrared sensor thermometer on the tympanic membrane and in the frontal area in afebrile children. Their conclusion was that the axillary temperature had the least dispersion of measured values and that the least reliable were temperature values measured on the tympanic membrane (9).
Except for the differences in the total sample, in our research, there are statistically significant differences in body temperature values in male subjects and in patients up to 55 years and between $55-70$ years of age, while body temperature values measured with the infrared sensor thermometer were higher than the values measured in the axilla and on the tympanic membrane.

In this research we wanted to determine if there are any differences with regard to the patient diagnosis, and there is a statistically significant difference in body temperature values in patients with COPD, where body temperature values were higher when measured with the infrared sensor thermometer than when other two methods of body temperature measurement were used (in the axilla and on the tympanic membrane).

Lawson and associates compared oral, axillary, temporal artery and tympanic membrane temperature measurements with the body temperature values measured in the pulmonary artery. They have concluded that the body temperature values measured orally and on the temporal artery were most accurate and most precise. In their research body temperature values measured in the axilla where lower than body temperature values measured in the pulmonary artery, and they state that the most precise values were obtained while measuring temperature on the tympanic membrane (6).

While measuring body temperature it is necessary to give special attention to the procedure since measurement irregularities can affect the measured body temperature values (7). In order to reduce the possibility of differences in the measured values, in our research all measurements were performed by the same researcher keeping in mind the standardized measuring procedure.

The research that was conducted in the Pediatric unit of the Children's Hospital Boot Hall in Manchester had the goal to research the variability of body tempera- 
ture measured on the tympanic membrane. Measurements were conducted in both ears on afebrile children with burns, and the differences in the results were around $0.6^{\circ} \mathrm{C}$. With febrile children differences in the temperature measured in the left and right ear were around $0.4-0.8^{\circ} \mathrm{C}$. In their conclusion they have stated the importance of measuring the temperature using the standardized procedure, and the need for repeated measurements in both ears (10).

A research that was conducted on 20 patients with the total of 102 measurements compared the body temperature values received by measurements using an artery catheter and on the tympanic membrane. Comparison of the measurements on the tympanic membrane, in both ears, showed high variability with the percentage of mistakes of $34.4 \%$. Temperature measurements on the tympanic membrane showed high variability in relation to the other method of measurement, and authors recommend a combination of the two measurements in hemodynamic unstable patients (11).

Guliano and associates conducted a research in an intensive care unit on 72 patients. They have conducted body temperature measurements on the tympanic membrane and orally. The obtained results showed differences in the measurements on the tympanic membrane with regard to the thermometer manufacturer. The total number of variables was lower in oral thermometer measurements. As a conclusion, they recommend measuring the body temperature using the oral thermometer only if it is not possible to insert a pulmonary catheter in hemodynamic unstable patients (12).

Even though numerous research indicate the advantages of oral measurement of body temperature, it is not used in our clinical practice.

By observing the average values of body temperature measured at different places on the body (in the axilla, on the tympanic membrane and using the infrared sensor thermometer measuring on the patient's forehead) we can see that the differences are very small and though they are statistically significant they do not present a significant difference in the clinical practice. While evaluating the patient's condition using the measured body temperature it is important to evaluate the overall condition of the patient and observe any other possible signs of elevated body temperature, and to repeat the measurement procedure at the same place or alternative places using alternative procedures.

\section{Conclusion}

The research found a statistically significant difference between the body temperature values obtained using the infrared sensor thermometer on the patients' forehead and the values measured in the axilla and on the tympanic membrane in the total patient sample, male patients, patients younger than 71 years of age and in patients with COPD. The values obtained using the infrared sensor thermometer are higher compared to the ones measured using other methods of measurement.

It is important to choose an appropriate method of body temperature measurement taking in account the particularities and the patient's clinical condition, advantages and disadvantages of each measurement procedure. Very often it is necessary to combine or repeat measurements to be completely certain in the obtained values. With patients in pulmonary intensive care units we recommend temperature measurement in the axilla, although using a classic thermometer takes longer when compared to the temperature being measured on the tympanic membrane or with the infrared sensor thermometer on the patient's forehead.

In patients who sweat profusely, body temperature when measured with the infrared sensor thermometer on the forehead can be higher compared to other two methods of measurement.

While measuring the body temperature it is important to adhere to the standardized measuring procedures.

Although a statistically significant difference has been observed, it is not clinically meaningful because the measured values are not very high in range. 


\section{References}

1. Prlić N. Zdravstvena njega. Zagreb: Školska knjiga; 1999. Croatian.

2. Guyton AC, Hall JE. Medicinska fiziologija. 12 izd. Zagreb: Medicinska naklada; 2012. Croatian.

3. Rogić M. Kratki vodič za medicinske sestre. Zagreb: Hrvatska komora medicinskih sestara; 2009. Croatian.

4. Čukljek S. Osnove zdravstvene njege. Zagreb: Zdravstveno veleučilište; 2005 . Croatian.

5. Cuesta-Frau D, Varela-Entrecanales M, Valor-Perez R, Vargas $B$. Development of a novel scheme for longterm body temperature monitoring: a review of benefits and applications. J Med Syst. 2015;39(4):209. doi: 10.1007/s10916-015-0209-3.

6. Lawson L, Bridges EJ, Ballou I, Eraker R, Greco S, ShiveIy J, et al. Accuracy and precision of noninvasive temperature measurement in adult intensive care patient. Am J Crit Care. 2007; 16(5):485-96.
7. Bridges E. Noninvasive measurement of Body temperature in critically ill patients. Crit Care Nurse 2009; 79 (3): 94-97.

8. Barringer LB, Evans CW, Ingram LL, Tisdale PP, Watson SP, Janken JK. Agreement between temporal artery, oral, and axillary temperature measurements in the perioperative period. J Perianesth Nurs. 2011; 26(3):143-50. doi: 10.1016/j.jopan.2011.03.010.

9. Antabak A, Šiško J, Romić I, Papeš D, Pasini M, Halužan $D$, i sur. Timpanična, frontalna i aksilarna temperatura u djece. Liječ Vjesn. 2016;138(1-2):30-3. Croatian.

10. Childs C, Harrison R, Hodkinson C. Tympanic membrane temperature as a measure of core temperature. Arch Dis Child. 1999; 80(3): 262-6.

11. Sanderson B, Lim L, Smith J, Camporota L, Beale R. A comparison of core and tympani temperature measurement in the critically ill. Crit Care. 2010; 14 Suppl 1: P329. https://doi.org/10.1186/cc8561

12. Giuliano KK, Giuliano AJ, Scott SS, MacLachlan E, Pysznik E, Elliot $S$, et al. Temperature measurement in critically ill adults: a comparison of tympanic and oral methods. Am J Crit Care. 2000;9(4):254-61. 


\section{RAZLIKA U TJELESNOJ TEMPERATURI MJERENOJ NA MEMBRANI TIMPANI, AKSILARNO} I INFRACRVENIM TOPLOMJEROM U PULMOLOŠKIH INTENZIVNIH BOLESNIKA

\section{Sažetak}

Uvod. Mjerenje tjelesne temperature u bolesnika u jedinici intenzivne skrbi standardni je postupak koji daje brzi uvid u stanje bolesnika i u eventualne promjene stanja. Mjerenje se provodi na različitim mjestima i uz pomoć različitih toplomjera. Bolesnici u jedinicama intenzivne skrbi hemodinamički su nestabilni, podvrgnuti raznim invazivnim metodama te tjelesna temperatura pokazuje moguće promjene u stanju bolesnika.

Cilj. Cilj istraživanja bio je utvrditi postoje li razlike u izmjerenim vrijednostima tjelesne temperature ovisno o načinu mjerenja, i to u vrijednostima izmjerenima aksilarno, na membrani timpani i infracrvenim toplomjerom na čelu bolesnika ovisno o dobi, spolu i dijagnozi bolesnika.

Ispitanici i metode. Istraživanje je provedeno na odjelu intenzivne skrbi Klinike za plućne bolesti Jordanovac u razdoblju od 2. siječnja do 2. srpnja 2017. Autorica istraživanja samostalno je mjerila tjelesnu temperaturu svim ispitanicima u svojoj smjeni. U istraživanje je uključeno sto bolesnika. Primijenjena je deskriptivna statistika (mjere centralne tendencije (aritmetička sredina, medijan, mod) i mjere varijabiliteta (standardna devijacija, minimum i maksimum), a rađena je i jednosmjerna analiza varijance (ANOVA) na ponovljenim mjerenjima (One-way Repeated Measures ANOVA).

Rezultati. Utvrđena je statistički značajna razlika u izmjerenim vrijednostima tjelesne temperature između vrijednosti dobivenih infracrvenim toplomjerom na čelu bolesnika, koje su bile više u odnosu na izmjerene aksilarno i na membrani timpani kod bolesnika muškog spola, bolesnika mlađih od 71 godinu i kod bolesnika oboljelih od KOPB-a.

Zaključak. Važno je odabrati odgovarajući način mjerenja tjelesne temperature uzimajući u obzir osobitosti i kliničko stanje pacijenta te prednosti i nedostatke pojedinog postupka mjerenja. Često je potrebno kombinirati ili ponavljati postupke mjerenja kao bismo bili u potpunosti sigurni u dobivenu vrijednost. Kod bolesnika u pulmološkim jedinicama intenzivnog liječenja preporučili bismo aksilarno mjerenje tjelesne temperature.

Ključne riječi: tjelesna temperatura, membrana tympani, aksilarno, infracrveni toplomjer 